\title{
Ecological factors determining the distribution of the red-bellied guenon Cercopithecus e. erythrogaster in Benin and Togo
}

\author{
Georges NOBIME $^{1 *}$, Brice SINSIN ${ }^{1}$ and Jean-Marc LERNOULD ${ }^{2}$ \\ ${ }^{1}$ Laboratoire d'Ecologie Appliquée, Faculté des Sciences Agronomiques, Université d'Abomey-Calavi, Bénin. \\ ${ }^{2}$ Conservation des Espèces et de Populations Animales, France. \\ *Auteur correspondant,Email: gnobime@yahoo.fr
}

\begin{abstract}
The red-bellied guenon (Cercopithecus e. erythrogaster) is an endangered subspecies of primate endemic to the Dahomey Gap. To better understand its distribution pattern, interviews with local people in 180 localities in south Benin and southeast Togo and ground surveys were conducted from 2000 to 2007. The species was found inhabiting eight localities in swamp forests, gallery forests and seasonally-flooded semideciduous forests. Two of these are protected areas: the Lama Forest of Benin and the Togodo Reserve of Togo. Appropriate conservation actions are necessary for the red-bellied guenon, including improved law enforcement and regular monitoring.

(C) 2009 International Formulae Group. All rights reserved.
\end{abstract}

Key words: Red-bellied guenon, Cercopithecus e. erythrogaster, distribution, Benin, Togo, conservation.

\section{INTRODUCTION}

The originally named museum skin of Cercopithecus erythrogaster has red hair on its chest and abdomen and may have originated in Benin. Grubb et al. (1999) recognized that there are two subspecies: Cercopithecus e. pococki from Nigeria and Cercopithecus e. erythrogaster Gray 1866 from Benin. C. e. pococki has a grey belly and C. e. erythrogaster a red belly. The relatively recent confirmation that the red-bellied guenon survives in southern Benin, exemplifies the lack of ecological studies and biodiversity surveys in the Dahomey Gap. A wild population of red-bellied guenons was discovered in 1994 (Oates, 1996). We are sure people had seen them before; but Oates was the first to publish a sighting with a geographical distribution limited to forests of the southern Benin (Oates, 1996; Sinsin et al., 2002). Further information about the spatial distribution of the subspecies and the characterization of its remaining habitats are particularly important to ensure the survival of this endangered taxon (Sinsin et al., 2002; Campbell et al., 2008). Conservation agencies and scientists have acknowledged the necessity for spatial knowledge of biodiversity for purposes of planning, management and conservation evaluation (Acharya, 1999).

Here we map the current distribution of the subspecies $C$. e. erythrogaster, provide evidence of its presence in Togo, and assess the ecological factors which impact its distribution and continued existence.

\section{MATERIALS AND METHODS}

\section{Study area}

This study took place in Southern Benin and in Southeast Togo between $1^{\circ} 30$ and $2^{\circ} 50$ East longitudes and between $6^{\circ} 20$ and $8^{\circ}$ North latitude. From an ecological perspective, this region covers four habitat types within a forest-savannah mosaic: dry 
semi-deciduous forest, seasonally humid semi-deciduous forest, swamp forest and gallery forest.

Benin and Togo are located within the so-called Dahomey Gap, in which Sudan-type savanna vegetation extends as far as the sea, through a hiatus in the West African rain forest, covering some $200 \mathrm{~km}$ from South East Ghana to South East Benin (Guillaumet, 1967; Schnell, 1976; Onochie, 1979; Whitmore, 1990; Martin, 1991; Maley, 1996; Salzmann and Hoelzmann; 2005). Nevertheless in areas where topography favours the semi-permanent presence of water, elements of the humid forest and its associated fauna have been retained (Adjanohoun, 1968; Kokou, 1998; Kokou et al., 1999; Le Gall et al., 2002). Currently, across the entire Dahomey Gap, the original pattern of vegetation is largely obscured by the omnipresent impact of dense human settlements and ever increasing exploitation through agriculture (Jenik, 1994; Kokou and Caballé, 2000). This human influence has reduced humid forest cover to isolated forest islands and riparian forests stretching along rivers.

\section{Data collection}

Nobimè visited dry and humid forest islands, riparian forests, and stream vegetation areas in the administrative departments of South Benin (Atlantique, Ouémé, Plateau, Mono, Couffo, Colline and Zou) and South Togo (Maritime). The studies took place in a total of 180 localities among rural villages situated in the districts of Sakété, Zangnanado, Abomey, Allada, Bopa, Dogbo, Lalo, Athièmè, Djakotomey, Toviklin, Pobè, Kétou, Savè and Aplahoué, and in the Ouémé river valley, as well as in the Lama depression and localities near Togodo reserve (Tabligbo district) in Togo.

The approach was to conduct an interview survey of local people (and especially with local authorities and hunters) in areas considered likely to harbor the redbellied guenon. Interviews with the local population throughout the different phases of the study provided information concerning the species' habits, past presence, and the localities where it could still be encountered. A poster featuring good-quality images of several guenon species was employed to ensure differential identification of the monkey in question by the surveyed persons. Once localities had been identified with the local population as having a past or present guenon presence, surveys within the species habitat were conducted. Of the 180 localities where the population was interrogated, direct surveys of potential habitats was undertaken in eight.

\section{RESULTS}

\section{Spatial distribution and habitat types}

Of 180 localities surveyed, 62 were identified by the inhabitants as having had a red-bellied guenon population at some stage; eight of these localities continue to harbor the subspecies, as confirmed by direct observation (Figure 1; Table 1). This included the first sighting of the red-bellied guenon in Togo, where Nobimè observed two polyspecific groups of red-bellied guenons and mona monkeys (Cercopithecus mona) in the Togodo Reserve.

\section{Causal factors of the presence of red- bellied guenon}

The areas where people reported that the red-bellied guenon was previously found are characterized by humid habitats: swamp forests, gallery forests and dense semideciduous forests, which are flooded in the rainy season. In addition to the protected forests of Lama and Togodo, the wetland vegetation of the Ouémé River, the swamp forest of Lokoli, and the gallery forests of Opkara and Mono are presently the preferred habitat of the red-bellied guenon.

\section{Major causes of red-bellied guenon habitat degradation.}

Pressures exercised by villagers as they continue to cut trees for firewood and to clear land for agriculture, lead to a forecast of continuing decline in the monkey's occupation area. Riparian forests provide fertile soil for cultivation, so in the MonoCouffo department the local human population has already entirely destroyed the gallery forests.

All hunters in the Mono gallery forest in Benin and Togo are based in Benin for poaching in Togodo reserve. This reserve is the only one with high animal biodiversity (primates, antelopes, buffalo, and lion) in the region. 
G. NOBIME et al. / Int. J. Biol. Chem. Sci. 3(3): 606-611, 2009

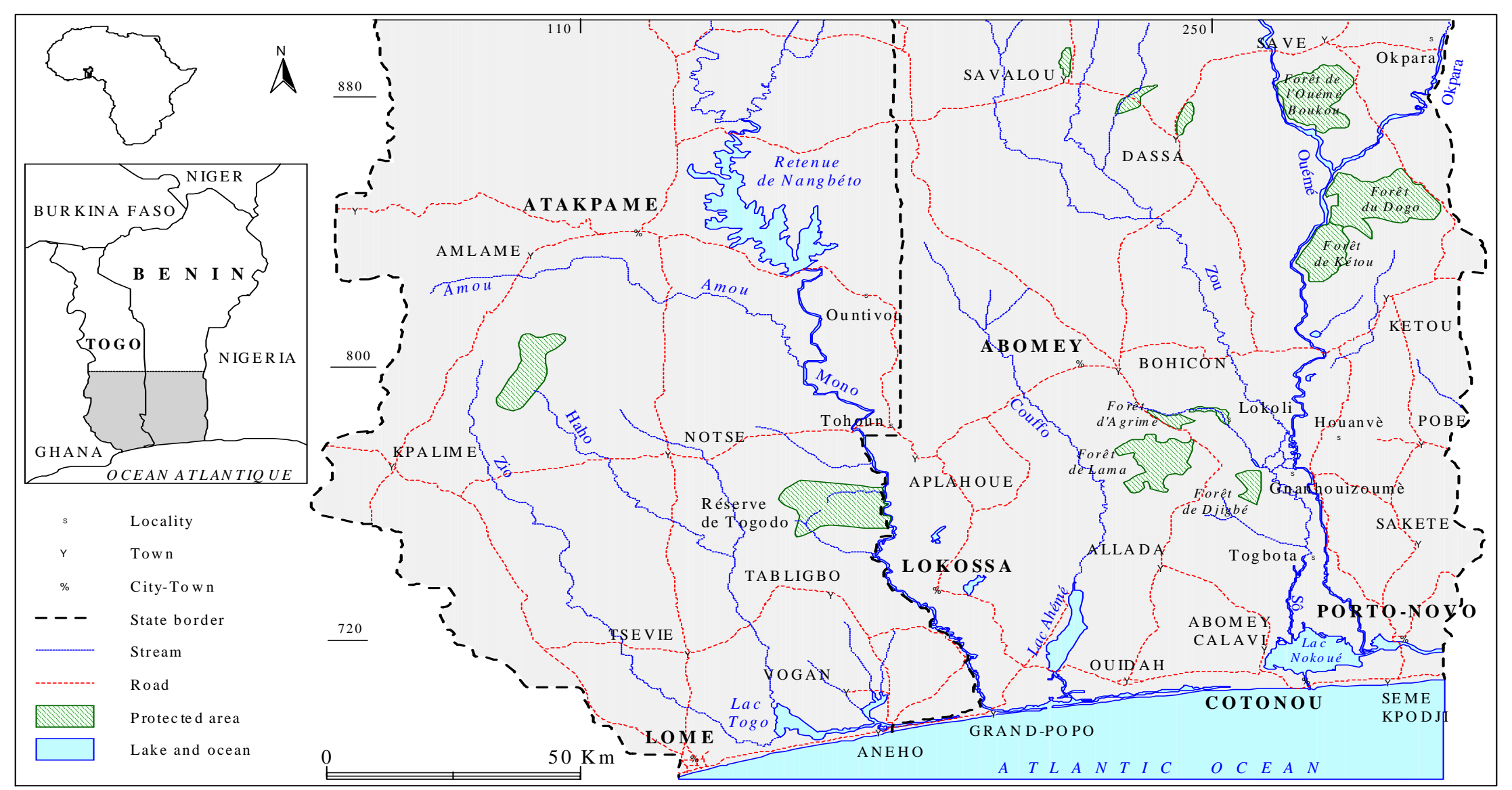

Figure 1: Surveyed zone for red-bellied guenon in Benin and Togo. 
Table 1: Features of localities where red-bellied guenons occur in Benin and Togo.

\begin{tabular}{|c|c|c|c|c|c|}
\hline Locality & $\begin{array}{c}\text { Habitat } \\
\text { area (ha) }\end{array}$ & Vegetation type & Human encroachment & Fragmented & Habitat type \\
\hline $\begin{array}{l}\text { Lama protected } \\
\text { forest (Benin) }\end{array}$ & 16,250 & $\begin{array}{l}\text { Dense semi-deciduous forest (Diospyros mespiliformis, } \\
\text { Dialium guineense, Cynometra megalophylla) }\end{array}$ & Protected area: poaching & No & $\begin{array}{l}\text { Seasonal } \\
\text { swamp forest }\end{array}$ \\
\hline Lokoli (Benin) & 500 & $\begin{array}{l}\text { Dense semi-deciduous forest (Raphia hookeri, Alstonia } \\
\text { congensis, Xylopia rubescens, Ficus congensis) }\end{array}$ & $\begin{array}{l}\text { Community forest: tree cutting, } \\
\text { farming, raphia palm } \\
\text { exploitation }\end{array}$ & Yes & Swamp forest \\
\hline $\begin{array}{l}\text { Gnanhouizoumè } \\
\text { (Benin) }\end{array}$ & 50 & $\begin{array}{l}\text { Dense semi-deciduous forest (Diospyros mespiliformis, } \\
\text { Dialium guineense, Cynometra megalophylla) }\end{array}$ & $\begin{array}{l}\text { Community forest: tree cutting, } \\
\text { farming }\end{array}$ & Yes & $\begin{array}{l}\text { Seasonal } \\
\text { swamp forest }\end{array}$ \\
\hline Togbota (Benin) & $5-10$ & $\begin{array}{l}\text { Dense semi-deciduous forest (Diospyros mespiliformis, } \\
\text { Dialium guineense, Cynometra megalophylla, Cola } \\
\text { laurifolia, Berlinia grandiflora, Pterocarpus santalinoides) }\end{array}$ & $\begin{array}{l}\text { Community forest: tree cutting, } \\
\text { farming }\end{array}$ & Yes & Gallery forest \\
\hline Houanvè (Benin) & 3 & $\begin{array}{l}\text { Riparian forest (Cola laurifolia, Berlinia grandiflora, } \\
\text { Pterocarpus santalinoides) }\end{array}$ & $\begin{array}{l}\text { Community forest: tree cutting, } \\
\text { farming }\end{array}$ & Yes & Gallery forest \\
\hline Okpara (Benin) & $3-5$ & $\begin{array}{l}\text { Riparian forest (Cola laurifolia, Berlinia grandiflora, } \\
\text { Pterocarpus santalinoides) }\end{array}$ & $\begin{array}{l}\text { Community forest: tree cutting, } \\
\text { farming }\end{array}$ & Yes & Gallery forest \\
\hline Mono (Benin, Togo) & $0.5-1$ & $\begin{array}{l}\text { Riparian forest (Cola laurifolia, Berlinia grandiflora, } \\
\text { Pterocarpus santalinoides) }\end{array}$ & $\begin{array}{l}\text { Community forest: tree cutting, } \\
\text { farming }\end{array}$ & Yes & Gallery forest \\
\hline $\begin{array}{l}\text { Togodo reserve } \\
\text { (Togo) }\end{array}$ & 31,000 & $\begin{array}{l}\text { Dense semi-deciduous forest and riparian forest (Diospyros } \\
\text { mespiliformis, Dialium guineense, Cynometra megalophylla, } \\
\text { Cola laurifolia, Berlinia grandiflora, Pterocarpus } \\
\text { santalinoides) }\end{array}$ & $\begin{array}{l}\text { Protected area: poaching and } \\
\text { tree cutting }\end{array}$ & No & Gallery forest \\
\hline
\end{tabular}




\section{DISCUSSION}

The red-bellied guenon, present in gallery forests, wetland and swamp forests of Southern Benin and Togo, is an endemic subspecies of the Dahomey Gap.

During a humid phase of the Holocene, the Dahomey Gap was probably covered with evergreen lowland forest (Salzmann and Hoelzmann, 2005). This suggests that extant patches of natural forest in Southern Benin are remnants of the former semi-evergreen lowland forest that has been largely destroyed by humans. For species distributed in the lowland rainforest during the Holocene, these forest remnants, such as the Lama protected forest, are important refuges (Nagel et al., 2004).

According to Levaux (1990), Roggeri (1995) and Brugière et al. (1999), riparian forests are important in the conservation of a large range of plants and animals, constituting a natural habitat or the last refuge for many species, but also they contain many endemic species and threatened species. The Ouémé River and its forested banks are rich in bird life, and serve as a focal point of primates and animals of many kinds (Natta, 2003), including the red-bellied guenon. In the redbellied guenon habitat, there is little human activity for the three months or more per year when the area is flooded, providing therefore a good refuge (Sinsin et al., 2002).

Our studies have also shown that the red-bellied guenon is present in gallery forests of the Mono River system, including the Togodo Reserve of Togo.

\section{Conclusions and recommendations for conservation}

Human pressures in Benin and Togo have led to the degradation, destruction and fragmentation of riparian gallery forests. They are now endangered ecosystems. Although small in size, the remaining seasonallyflooded and riparian forests are important in the conservation of numerous animals and the Lama protected forest, the gallery forests of Oueme, Mono and Opkara, and the Lokoli swamp forest are important refuges for redbellied guenon. The uniqueness, vulnerability and diversity of these forests are the most important criteria rendering their protection a priority. Logging within the protected areas and riparian forests should be prevented, and limited within buffer zones around these areas. Law enforcement capabilities should be strengthened to reduce greatly illegal, unregulated and unmanaged hunting. Major donors and conservation bodies should be encouraged to put into place trust funds to support the required law enforcement, research, monitoring, evaluation, information and conservation education programs, especially in and around the existing protected areas (Lama protected forest, Togodo reserve) and the surviving riparian forests. This could be done within the context of a regional wetland conservation project covering Benin and Togo. The Benin and Togo governments must coordinate their actions against poachers in the Mono river region.

Domestic food alternatives to bushmeat and alternative livelihoods should be developed and promoted, particularly around protected areas and riparian forests. These measures might include small mammal breeding, fish breeding, bee keeping, and mushroom production.

The Dahomey Gap's populations of primates should be regularly surveyed and monitored so that numbers, distributions, trends, and threats are well known and appropriate conservation actions taken.

\section{ACKNOWLEDGEMENTS}

This study was conducted with the financial support of the Laboratoire d'Ecologie Appliquée (LEA), Conservation des Populations et Espèces Animales (CEPA) and Conservation International (CI). The authors are grateful to Dr. Aristide Adomou, Prof John Oates and the anonymous reviewers for their contribution of this manuscript.

\section{REFERENCES}

Acharya B. 1999. Forest biodiversity assessment: A spatial analysis of tree species diversity in Nepal. PhD Thesis. ITC Forest Division, ITC Publication 72, Enschede, The Netherlands, 199p.

Adjanohoun E. 1968. Le Dahomey. Acta Phytogeographica Suecica, 54: 86-91

Brugière D, Sakom D, Gauthier-Hion A. 1999. Structure de la communauté des primates simiens de la forêt de Ngotto: importance des milieux marginaux dans le maintien de la biodiversité. Rapport ECOFAC. 51p. www.ecofac.org 
Campbell G, Teichroeb J, Paterson JD. 2008. Distribution of diurnal primates species in Togo and Benin. Folia Primatologica 79(1): 15-30.

Grubb P, Lernould JM, Oates JF. 1999. Validation of Cercopithecus erythrogaster pococki as the name for the Nigerian white-throated guenon. Mammalia, 63(3): 389-392.

Guillaumet JL. 1967. Recherche sur la végétation et la flore de la région du BasCavally (Côte-d'Ivoire). Mémoire ORSTOM 50, 247p.

Jenik J. 1994. The Dahomey-Gap: an important issue in African phytogeography. Mémoire de la Société Biogéographique ( $3^{\text {ème }}$ série), 4: 125-133.

Kokou K. 1998. Les mosaïques forestières au du Togo: Biodiversité, dynamique et activités humaines. Thèse Doctorat de l'Université de Montpellier II. Montpellier, France, 140p + Annexes.

Kokou K, Caballé G, Akpagana K, Batawila K. 1999. Les îlots forestiers au sud du Togo: Dynamique et relations avec les végétations périphériques. Revue d'Ecologie (Terre et Vie), 54: 301-314.

Kokou K, Caballé G. 2000. Les îlots forestiers de la plaine côtière togolaise. Bois et Forêts Tropicaux, 263(1) : 39-50.

Le Gall P, Goergen G, Neuenschwander P. 2002. Les insectes et le sillon dahoméen: fragmentation et refuges forestiers. Biosystema 20. Systématique et Biogéographie : 73-80.

Levaux P. 1990. Etude des relations faunevégétation sur transects au Parc National de la Pendjari au Bénin. Ecole Nationale du Génie Rural des Eaux et Forêts. Centre de Montpellier, France, 37p + annexes.

Maley J. 1996. The African rain forest - main characteristics of changes in vegetation and climate from upper cretaceous to the quaternary. In Essays on the Ecology of the Guinea-Congo Rain Forest, Alexander IJ, Swaine MD, Watling R (eds). Proceedings of the Royal Society of Edinburgh; 104B: 31-73.
Martin C. 1991. The Rainforests of West Africa. Birkhauser Verlag Publishers: Basel, Switzerland; 235p.

Nagel P, Sinsin B, Peveling R. 2004. Conservation of biodiversity in a relic forest in Benin. Regio Basiliensis: 125137.

Natta AK. 2003. Ecological assessment of riparian forests in Benin: Phytodiversity, phytosociology, and spatial distribution of tree species. PhD Thesis, Wageningen University, Pays-Bas, 215p.

Oates JF. 1996. Survey of Cercopithecus erythrogaster population in the Dahomey Gap. African Primates, 2(1): 9-11.

Onochie CFA. 1979. The Nigerian rainforest ecosystem. In The Nigerian Rainforest ecosystem. Proceedings of the Man and Biosphere Workshop on the Nigerian rainforest Ecosystem, Okali DUU (ed). University of Ibadan 24-26 january 1979. Ibadan: Nigeria; 1-37.

Roggeri H. 1995. Zones Humides Tropicales d'Eau Douce. Guide des Connaissances Actuelles et de la Gestion Durable. WIW, Union Européenne, Université de Leiden. Kluwer Academic Plublishers: Pays-Bas; $385 \mathrm{p}$.

Salzmann U, Hoelzmann P. 2005. The Dahomey Gap: an abrupt climatically induced rain forest fragmentation in West Africa during the late Holocene. The Holocene: 1-10.

Schnell R. 1976. La Flore et la Végétation de l'Afrique Tropicale (Vol. 3, $1^{\text {ère }}$ partie). Edition Gauthier-Villars: Paris, France; 460p.

Sinsin B, Nobimè G, Téhou A, Bekhuis $\mathrm{P}$, Tchibozo S. 2002. Past and present distribution of red-bellied monkey Cercopithecus erythrogaster erythrogaster in Benin. Folia Primatologica, 73: 116-123.

White F. 1983. The vegetation of Africa, a descriptive memoir to accompany the UNESCO/AETFAT/UNSO, UNESCO, Natural Resources Research, 20: 1-356.

Whitmore TC. 1990. An Introduction to Tropical Rain Forests. Clarendon Press: Oxford; 225p. 